18 Rush RL, Leon L, Turrel J. Automated simultaneous cholesterol and triglyceride determination on the Auto-Analyzer II instrument. Advances in
automated analysis. Vol 1. Miami, Florida: Thurman Associates, 1971:503-7.

19 Burstein M, Samaille J. Sur un dosage rapide de cholésterol lié au alpha- et bétalipoprotéins du sérum. Clin Chim Acta 1955;5:609.

20 Collen MF, Cutler JL, Siegelaub AB, Cella RL. Reliability of a selfadministered medical questionnaire. Arch Intern Med 1969;123:664-71.

21 Brownlee KA. Statistical theory and methodology in science and engineering. New York: Wiley, 1965

22 Cerasi $E$, Luft $R$. The plasma insulin response to glucose infusion in healthy subjects and in diabetes mellitus. Acta Endocrinol 1967;55:278-304.

23 Hulley SB, Furberg CD, Gurland B, et al. Systolic hypertension in the elderly program (SHEP): antihypertensive efficacy of chlorthalidone. $A m \mathcal{f}$ Cardiol 1985;56:913-20.

24 Castelli WP. The triglyceride issue: a view from Framingham. Am Heart $f$ 1986;112:432-7.
25 Åberg H, Lithell H, Selinus I, Hedstrand H. Serum triglycerides are a risk factor for myocardial infarction but not for angina pectoris. Results from 10-year follow-up of Uppsala primary preventive study. Atherosclerosis 1985;54:89-97.

26 Pyörälä K. Relationship of glucose tolerance and plasma insulin to the incidence of coronary heart disease: results from two population studies in Finland. Diabetes Care 1979;2:131-41.

27 Ducimetiere P, Eschwege E, Papoz L, Richard JL, Claude JR, Rosselin G. Relationship of plasma insulin levels to the incidence of myocardial infarction and coronary heart disease mortality in a middle-aged population Diabetologia 1980;19:205-10.

28 Welborn TA, Wearne K. Coronary heart disease incidence and cardiovascula mortality in Busselton with reference to glucose and insulin concentrations. Diabetes Care 1979;2:154-60.

(Accepted 3 February 1989)

\title{
Sensitivity to insulin during treatment with atenolol and metoprolol: a randomised, double blind study of effects on carbohydrate and lipoprotein metabolism in hypertensive patients
}

\author{
Thomas Pollare, Hans Lithell, Ingemar Selinus, Christian Berne
}

\section{Abstract}

Objective-To compare the effects of metoprolol and atenolol on carbohydrate and lipid metabolism and on insulin response to an intravenous glucose load.

Design-Randomised, double blind, double dummy, controlled crossover trial.

Setting - University Hospital, Uppsala, Sweden.

Patients -60 Patients with primary hypertension (diastolic blood pressure when resting supine 95-119 $\mathrm{mm} \mathrm{Hg}$ on at least two occasions during four to six weeks of treatment with placebo) randomised to receive either metoprolol $(n=30)$ or atenolol $(n=30)$ during the first treatment period.

Interventions-Placebo was given for a run in period of four to six weeks. Metoprolol $100 \mathrm{mg}$ twice daily or atenolol $25 \mathrm{mg}$ twice daily was then given for 16 weeks. The two drugs were then exchanged and treatment continued for a further 16 weeks.

End point-Evaluation of effects of treatment with metoprolol and atenolol on glucose, insulin, and lipid metabolism and glucose disposal mediated by insulin.

Measurements and main results-Reduction of blood pressure was similar and satisfactory during treatment with both drugs. Glucose uptake mediated by insulin was measured during a euglycaemic hyperinsulinaemic clamp to evaluate patients' sensitivity to insulin. Glucose uptake decreased from 5.6 to 4.5 $\mathrm{mg} / \mathrm{kg} / \mathrm{min}$ when patients were taking metoprolol and from 5.6 to $4.9 \mathrm{mg} / \mathrm{kg} / \mathrm{min}$ when they were taking atenolol. Both.drugs caused a small increase in fasting plasma insulin and blood glucose concentrations and glycated haemoglobin concentration. Despite decreased sensitivity to insulin the increase in insulin concentration in response to an intravenous glucose tolerance test was small, suggesting inhibition of release of insulin. Very low density lipoprotein and low density lipoprotein triglyceride concentrations were increased with both drugs and high density lipoprotein cholesterol concentration was decreased. Low density lipoprotein cholesterol concentration was not affected.

Conclusions-Long term use of metoprolol and atenolol causes metabolic abnormalities that may be related to the increased incidence of diabetes in patients with hypertension who are treated pharmacologically. These results may help to explain why the two drugs have failed consistently to reduce the incidence of coronary heart disease in several large scale studies.

\section{Introduction}

During the past 20 years there has been much emphasis on detecting and treating hypertension, which is an important risk factor for cardiovascular disease, ${ }^{1}$ and several large scale trials have shown that a reduction in blood pressure is associated with a decrease in cardiovascular morbidity and mortality. ${ }^{2.5}$ Some of the drugs used to treat hypertension, however, have adverse effects, including disturbances of serum lipid concentrations and glucose metabolism. ${ }^{5.7}$ Treatment with thiazide diuretics and $\beta$ blockers has been associated with an increased incidence of impaired glucose tolerance ${ }^{6}$ and diabetes. ${ }^{57}$ Few attempts have been made, however, to evaluate specific influences of pharmacological treatment of hypertension on glucose metabolism-for example, to determine whether it decreases secretion of insulin or sensitivity to insulin, or both. Sensitivity, to insulin may be important as studies have shown that hypertension is accompanied by resistance to insulin..$^{8-10}$

We evaluated the effect of long term treatment with two widely used $\beta_{1}$ adrenergic blockers, metoprolol and atenolol, on glucose disposal mediated by insulin and examined their effects on glucose, insulin, and lipid metabolism.

\section{Patients and methods}

\section{CRITERIA FOR INCLUSION}

Patients were recruited from a health screening survey in Uppsala, Sweden. All had primary hypertension, defined as a stable diastolic blood pressure when resting supine of $95-119 \mathrm{~mm} \mathrm{Hg}$ on at least two occasions during four to six weeks of treatment with placebo. Any current antihypertensive treatment was stopped and a placebo was given single blind for four to six weeks. Patients with newly detected hypertension were followed up for three to four months to make sure that their raised blood pressure was stable before they entered the single blind placebo period.

\section{CRITERIA FOR EXCLUSION}

Criteria for exclusion were: clinical or laboratory evidence of hepatic or renal disease, obstructive pulmonary disease, Raynaud's disease, or thyroid dys- 
function; a history of cardiovascular disease, major gastrointestinal surgery, or renal impairment; diabetes (except in one subject with non-insulin dependent diabetes controlled by diet); other endocrine diseases; contraindications to treatment with $\beta$ blockers; and treatment with drugs for other diseases.

\section{DESIGN OF STUDY}

The study was a controlled, randomised (with a block size of four), double blind, double dummy crossover trial done over nine months divided into three treatment periods. The first period was a single blind washout phase (four to six weeks) during which the patients were given one placebo that matched atenolol and one placebo that matched metoprolol twice daily. In the second period (four months) the patients were randomised and given fixed doses of either metoprolol $100 \mathrm{mg}$ twice daily $(n=30)$ or atenolol $25 \mathrm{mg}$ twice daily $(\mathrm{n}=30)$ and placebo that matched the alternative drug. During the third period (four months) metoprolol and atenolol were exchanged.

Compliance with treatment was assessed in all patients by interview and pill count. Subjective symptoms were evaluated by visual analogue scales. Questions were asked about physical activity during leisure and at work and answers indicated on a four point scale. Dietary habits were investigated. All patients entering the study were given a thorough physical examination by one doctor (TP), and all blood pressure measurements were made by the same two nurses. Metabolic investigations were performed at the end of each period in the morning, 10-14 hours after the last dose of the drug. The methods of these investigations have been described in another study. ${ }^{9}$

Fully informed consent was obtained from all subjects. The protocol was approved by the human ethics committee of the medical faculty of Uppsala University.

\section{BLOOD PRESSURE AND HEART RATE}

Systolic blood pressure was defined as Korotkoffphase I and diastolic as phase V. Measurements were made on the right arm to the nearest $\mathrm{mm} \mathrm{Hg}$ with a mercury sphygmomanometer: three measurements were made in the supine position after the patients had rested for 10 minutes, and two after they had stood for one minute. The means of these measurements were used in the analyses. A large cuff was used when appropriate. Heart rate was recorded before each blood pressure measurement.

\section{METABOLIC INVESTIGATIONS}

Blood samples were taken and urine collected after an overnight fast. An intravenous glucose tolerance test was performed by injecting $300 \mathrm{mg}$ glucose/ $\mathrm{kg}$ body weight. ${ }^{9}$ Plasma glucose concentration was determined by the glucose oxidase method (Optimate, Ames-Gilford). The rate of disappearance of glucose was expressed as a $\mathbf{k}$ value calculated from the formula $k=100 \times \log _{e} 2 / T^{1} 1 / 2 ; T^{1} 1 / 2$, the time (minutes) required for the glucose concentration to be halved, was determined from the best fit of the measured values on semilogarithmic paper. "Immunoreactive insulin in plasma was assayed by a commercial radioimmunoassay kit (Phadeseph insulin radioimmunoassay, Pharmacia). The peak insulin response was defined as the mean of the values obtained at two, four, and six minutes. The average fasting plasma insulin concentration was calculated from the values in four samples taken on two separate days. Glycated haemoglobin concentration was measured by high performance liquid chromatography. ${ }^{12}$ Lipoproteins were analysed by ultracentrifugation and precipitation (with phosphotungstate and magnesium chloride). Triglyceride and cholesterol concentrations were measured by enzymatic techniques (Boehringer Mannheim) with a Multistate III I/LS centrifugal analyser (Instrumentation Laboratories). Serum concentrations of free fatty acids were determined by an enzymatic colorimetric method with a commercial kit (Wako Chemicals) adapted for analysis with a Multistat III analyser. All other tests were carried out in the department of clinical chemistry of the University Hospital. Body mass index was calculated as weight $(\mathbf{k g}) /(\text { height }(\mathbf{m}))^{2}$.

\section{INSULIN SENSITIVITY}

The euglycaemic hyperinsulinaemic clamp technique was used to estimate the sensitivity of patients to insulin while they were taking placebo and at the end of each treatment period. ${ }^{13}$ The technique has been described in detail.' The rate of infusion of insulin (Actrapid Human, Novo) was $56 \mathrm{mU} / \mathrm{m}^{2} / \mathrm{min}$ in all subjects, resulting in a mean plasma insulin concentration of $98 \mathrm{mU} / \mathrm{l}$ (range 79-129). The chosen plasma glucose concentration during the clamp study was $5 \cdot 2$ $\mathrm{mmol} / \mathrm{l}$. The mean (SD) steady state plasma glucose concentration during the clamp in patients taking placebo was $5.2(0.3) \mathrm{mmol} / \mathrm{l}$, and there was no significant change in concentration during different treatment periods. The coefficient of variation for the steady state plasma glucose concentration for a single clamp was less than $4.5 \%$ on all occasions (mean 3.4 $(1.0 \%)$ ), and there were no significant changes in the coefficient of variation between different treatment periods.

The amount of glucose taken up ( $\mathrm{mg} / \mathrm{kg} / \mathrm{min}$ ) during each clamp study was calculated for each 20 minute interval after the first 20 minutes. The mean rate of glucose uptake for the last 60 minutes of the clamp was used as the main target variable. The index of sensitivity to insulin, a measure of sensitivity of tissue to insulin expressed per unit of insulin, was calculated by dividing the amount of glucose taken up by the mean insulin concentration during the same period of the clamp. ${ }^{13}$ The insulin concentrations attained during the insulin infusion (about $98 \mathrm{mU} / \mathrm{l}$ ) were sufficient to suppress production of glucose by the liver in hypertensive patients with insulin resistance.$^{81418}$ Urinary losses of glucose were negligible under euglycaemic conditions.

\section{STATISTICAL ANALYSES}

Two way analysis of variance was used to test changes within and between groups over time. As the data were unbalanced because subjects dropped out or values were missing, or both, the mean values were not suitable for comparison. The results are presented as least square means ${ }^{19}$ because they form the basis of the tests and estimates in the analysis and take the imbalance into account. The various tests of contrast use functions of the residual variance as the error term and not functions of the variance of the group multiplied by time. The square root of the residual variance is therefore presented in the tables. The results of the two arms combined are presented. All comparisons were made against the results obtained in the placebo period.

\section{Results}

\section{ANTIHYPERTENSIVE TREATMENT}

Sixty two patients met the criteria for entry and were enrolled in the placebo run in period, but two failed to qualify during this period. Thus 60 patients were given active drug treatment (table I). Twenty seven had been taking antihypertensive drugs before the placebo period: selective $\beta$ blockers (13), pindolol (4), diuretics (6), calcium channel blockers (5), and angiotensin converting enzyme inhibitors (3). Four patients had 
been receiving combined treatment. Two patients did not complete the last treatment period (with metoprolol in both cases). One withdrew because his hands and feet became cold when he was taking the drug; the other moved away from the area. The pill count showed good compliance (all subjects took $>95 \%$ of tablets). Diet and physical activity did not change during the study. There were no carryover effects between drugs, nor were there differences in the effects of the drugs between patients who had and had not been treated for hypertension previously.

\section{BLOOD PRESSURE}

The adjusted mean blood pressure, both supine and standing, decreased significantly during treatment with both drugs (table II). The reduction in supine

TABLE I-Clinical characteristics of hypertensive patients

\begin{tabular}{lcc}
\hline & Men $(\mathrm{n}=36)$ & Women $(\mathrm{n}=24)$ \\
\hline $\begin{array}{l}\text { No (\%) newly diagnosed as having } \\
\text { hypertension }\end{array}$ & $19(53)$ & $14(58)$ \\
$\begin{array}{l}\text { Mean (SD) age (years) } \\
\text { Mean (SD) body mass index }\left(\mathrm{kg} / \mathrm{m}^{2}\right)\end{array}$ & $56 \cdot 2(11 \cdot 9)$ & $57 \cdot 2(8 \cdot 1)$ \\
$\begin{array}{l}\text { Mean (SD) ratio of waist to hip } \\
\text { circumference }\end{array}$ & $0.95(0 \cdot 0)$ & $31 \cdot 2(6.4)$ \\
No (\%) smokers & $9(25)$ & $0.89(0.08)$ \\
& & $5(21)$ \\
\hline
\end{tabular}

pressure in all patients was $15 / 13 \mathrm{~mm} \mathrm{Hg}$ when they were taking atenolol and $14 / 12 \mathrm{~mm} \mathrm{Hg}$ when taking metoprolol. Both drugs caused a significant decrease in heart rate.

\section{INSULIN SENSITIVITY AND GLUCOSE UPTAKE}

Sensitivity to insulin decreased during treatment with metoprolol and atenolol in each clamp period of 20 minutes compared with the corresponding value during the clamp when the patients took placebo, although the area under the insulin curve during the clamp study increased by $7.6 \%(p=0.029)$ and $11 \%$ $(p=0.002)$ for metoprolol and atenolol respectively.

The mean glucose uptake (during the last 60 minutes of the clamp) during treatment with placebo was $5.6 \mathrm{mg} / \mathrm{kg} / \mathrm{min}$. This decreased by $1.1 \mathrm{mg} / \mathrm{kg} / \mathrm{min}$ $(p<0.0001)$ during treatment with metoprolol and by $0.7 \mathrm{mg} / \mathrm{kg} / \mathrm{min}(\mathrm{p}<0.0001)$ during treatment with atenolol. The difference between the two drugs was significant $(p=0.018)$.

The index of sensitivity to insulin for the last 60 minutes of the clamp decreased from $5 \cdot 8$ to 4.2 when patients were taking metoprolol $(p<0.0001)$ and from 5.8 to 4.5 when patients were taking atenolol $(p<0.0001)$, showing that disposal of glucose decreased during the two regimens. The difference between the two drugs was not significant (figure).

TABLE II-Adjusted mean systolic and diastolic blood pressures and heart rate in patients supine and standing while taking placebo, effects of metoprolol and atenolol, and difference between effects of the two active drugs

\begin{tabular}{|c|c|c|c|c|c|}
\hline Variable & $\begin{array}{l}\text { During treatment } \\
\text { with placebo }(n=60)\end{array}$ & $\begin{array}{c}\text { Effect of treatment } \\
\text { with metoprolol }(n=58)\end{array}$ & $\begin{array}{l}\text { Effect of treatment } \\
\text { with atenolol }{ }^{\star}(n=60)\end{array}$ & $\begin{array}{l}\text { Difference between effects } \\
\text { of metoprolol and atenolol }\end{array}$ & $\begin{array}{l}\text { Square root of } \\
\text { residual variance }\end{array}$ \\
\hline \multicolumn{6}{|c|}{ Systolic blood pressure $(\mathrm{mm} \mathrm{Hg})$ : } \\
\hline Supine & 163 & -14 & -15 & 1.4 & $10 \cdot 2$ \\
\hline Standing & 158 & -15 & -15 & $0 \cdot 3$ & $10 \cdot 0$ \\
\hline \multicolumn{6}{|c|}{ Diastolic blood pressure $(\mathrm{mm} \mathrm{Hg})$ : } \\
\hline Supine & 101 & -12 & -13 & $1 \cdot 3$ & $5 \cdot 2$ \\
\hline Standing & 105 & -12 & -12 & 0.2 & 5.5 \\
\hline \multicolumn{6}{|c|}{ Heart rate (beats $/ \mathrm{min})$ : } \\
\hline Supine & 69 & -9 & -9 & 0 & $5 \cdot 2$ \\
\hline Standing & 77 & -11 & -11 & 0 & $6 \cdot 3$ \\
\hline
\end{tabular}

${ }^{\star} \mathrm{p}<0.001$ For all values.
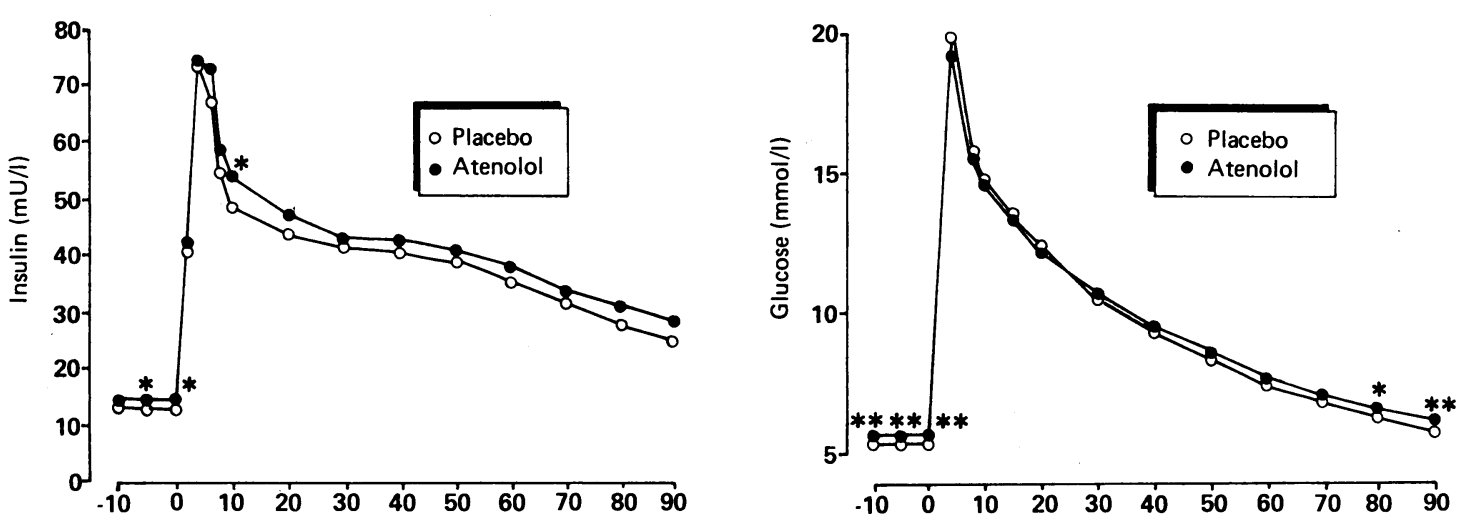

Plasma insulin and glucose concentrations during intravenous glucose tolerance test in 60 hypertensive patients receiving atenolol (top) and metoprolol (bottom). ${ }^{\star} p<0.05$, $\star \star p<0.01$
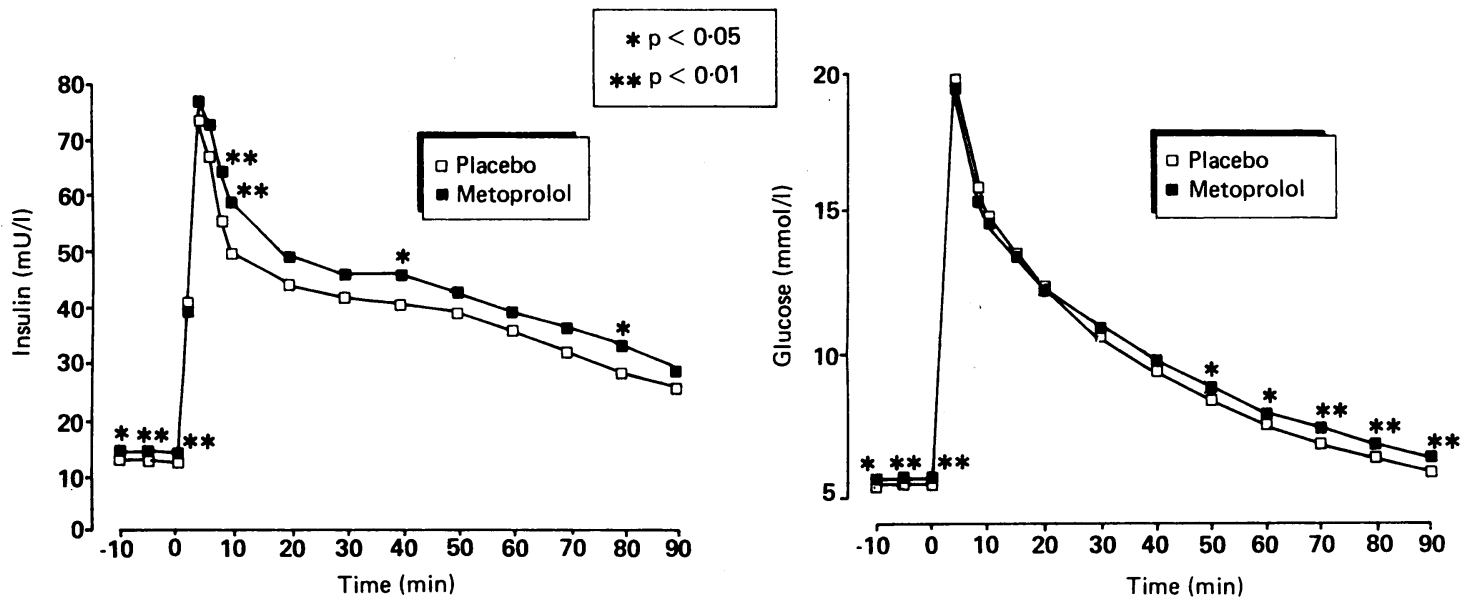
FASTING INSULIN AND GLUCOSE CONCENTRATIONS AND RESPONSE TO INTRAVENOUS GLUCOSE TOLERANCE TEST

Table III and the figure show data on fasting plasma insulin and glucose concentrations and other variables and the responses of plasma insulin and glucose concentrations during the intravenous glucose tolerance test before and after treatment with metoprolol and atenolol. Fasting plasma insulin concentration increased significantly during treatment with both drugs, and the insulin concentrations at the end of the glucose tolerance curve tended to be higher than during treatment with placebo. Plasma insulin concentrations were somewhat higher with metoprolol than atenolol, and peak insulin concentration was increased with metoprolol (from 65 to $71 \mathrm{mU} / 1, \mathrm{p}=0.042$ ). Fasting plasma glucose concentration also increased (significantly) during both treatment periods, as did glucose concentrations at the end of the glucose tolerance curve, with higher values during treatment with metoprolol.

The $\mathrm{k}$ value for the disappearance of glucose during the glucose tolerance test decreased during treatment with metoprolol $(p<0.05)$, and glycated haemoglobin concentration increased during treatment with both drugs $(p<0.001)$. Patients gained about $1 \mathrm{~kg}$ in weight during both drug regimens $(p<0.001)$ (table III).

TABLE III-Adjusted mean glycated haemoglobin $\left(H b A_{I C}\right)$ concentration, $k$ value obtained during glucose tolerance test, fasting plasma glucose and insulin concentrations, and body weight during treatment with placebo, metoprolol, and atenolol

\begin{tabular}{|c|c|c|c|c|}
\hline Variable & $\begin{array}{l}\text { During } \\
\text { treatment } \\
\text { with } \\
\text { placebo }\end{array}$ & $\begin{array}{c}\text { During } \\
\text { treatment } \\
\text { with } \\
\text { metoprolol }\end{array}$ & $\begin{array}{l}\text { During } \\
\text { treatment } \\
\text { with } \\
\text { atenolol }\end{array}$ & $\begin{array}{l}\text { Square } \\
\text { root of } \\
\text { residual } \\
\text { variance }\end{array}$ \\
\hline $\begin{array}{l}\mathrm{HbA}_{\mathrm{IC}}(\%) \\
\mathrm{k} \text { Value }(\% / \mathrm{min}) \\
\text { Plasma glucose }(\mathrm{mmol} / \mathrm{l}) \\
\text { Plasma insulin (mU/l) } \\
\text { Weight }(\mathrm{kg})\end{array}$ & $\begin{array}{c}4 \cdot 6 \\
1 \cdot 3 \\
5 \cdot 4 \\
13 \\
88 \cdot 0\end{array}$ & $\begin{array}{l}4 \cdot 9^{\star \star \star} \\
1 \cdot 1^{\star} \\
5 \cdot 6^{\star \star \star} \\
15^{\star \star} \\
89 \cdot 2^{\star \star \star}\end{array}$ & $\begin{array}{l}4 \cdot 9^{\star \star \star} \\
1 \cdot 2 \\
5 \cdot 6^{\star \star \star} \\
15^{\star} \\
89 \cdot 3^{\star \star \star}\end{array}$ & $\begin{array}{l}0 \cdot 5 \\
0 \cdot 4 \\
0 \cdot 5 \\
6 \\
8 \cdot 1\end{array}$ \\
\hline
\end{tabular}

${ }^{\star} \mathrm{p}<0.05,{ }^{\star \star} \mathrm{p}<0.01,{ }^{\star \star \star} \mathrm{p}<0.001$.

\section{SERUM LIPID CONCENTRATIONS}

Very low density lipoprotein triglyceride and cholesterol concentrations increased during treatment with both drugs (table IV), as did low density lipoprotein triglyceride concentration, but low density lipoprotein cholesterol concentration did not change. High density lipoprotein cholesterol concentration decreased during both drug regimens, but the high density lipoprotein triglyceride concentration did not change. The ratio of low density lipoprotein to high density lipoprotein cholesterol increased by $4 \cdot 4 \%$ ( $p=$ 0.074 ) during treatment with atenolol. The ratio of non-high density lipoprotein cholesterol to high den-
TABLE V-Subjective symptoms as evaluated by visual analogue scales during treatment with metoprolol and atenolol. No points were given for no disturbing symptoms and 100 points for intensive, maximally disturbing symptoms. Values are adjusted means

\begin{tabular}{|c|c|c|c|}
\hline Symptom & $\begin{array}{c}\text { During } \\
\text { treatment } \\
\text { with } \\
\text { placebo } \\
(\mathbf{n}=60)\end{array}$ & $\begin{array}{c}\text { During } \\
\text { treatment } \\
\text { with } \\
\text { metoprolol } \\
(\mathrm{n}=58)\end{array}$ & $\begin{array}{c}\text { During } \\
\text { treatment } \\
\text { with } \\
\text { atenolol* } \\
(\mathrm{n}=60)\end{array}$ \\
\hline Palpitations & 13.8 & 9.9* & $8 \cdot 0^{\star \star}$ \\
\hline Tachycardia & 11.9 & $7 \cdot 6^{\star}$ & $6 \cdot 3 \star \star$ \\
\hline Bradycardia & 3.9 & $7 \cdot 5^{\star \star}$ & $5 \cdot 6$ \\
\hline Irregular heart activity & $9 \cdot 6$ & 8.9 & $8 \cdot 2$ \\
\hline $\begin{array}{l}\text { Headache } \\
\text { Hen action }\end{array}$ & $26 \cdot 5$ & $18.5 *$ & $17 \cdot 8^{\star \star}$ \\
\hline Breathlessness and wheezing & $18 \cdot 7$ & $16 \cdot 1$ & $14 \cdot 3$ \\
\hline Sweating & $18 \cdot 3$ & $18 \cdot 6$ & 15.7 \\
\hline Skin symptoms & $5 \cdot 5$ & $6 \cdot 1$ & $5 \cdot 7$ \\
\hline Cold hands and feet & 20.0 & 22.7 & 23.6 \\
\hline General fatigue & $25 \cdot 2$ & 23.5 & $22 \cdot 3$ \\
\hline Muscular tiredness during effort & 12.9 & $15 \cdot 4$ & $14 \cdot 7$ \\
\hline Decreased physical endurance & $20 \cdot 4$ & 18.4 & 16.7 \\
\hline Difficulties in concentrating & 11.5 & $12 \cdot 9+$ & $9 \cdot 7 \dagger$ \\
\hline Irritability & 15.6 & 14.9 & $13 \cdot 0$ \\
\hline Forgetfulness & $16 \cdot 6$ & 14.9 & $16 \cdot 1$ \\
\hline Dizziness & $14 \cdot 2$ & 13.6 & $10 \cdot 3$ \\
\hline Sensations of fainting & 4.7 & 5.8 & 5.4 \\
\hline Nightmares & $6 \cdot 1$ & 8.9* & 6.7 \\
\hline Insomnia & $10 \cdot 6$ & $15 \cdot 8^{*}$ & 11.4 \\
\hline Waking up during the night & $16 \cdot 5$ & $20 \cdot 1$ & $15 \cdot 2$ \\
\hline Vivid dreams & $11 \cdot 0$ & $13.9+$ & $9.7 \dagger$ \\
\hline
\end{tabular}

${ }^{\star} \mathrm{p}<0.05, \star \star \mathrm{p}<0.01,{ }^{\star \star \star} \mathrm{p}<0.001$ Compared with treatment with placebo. tp $<0.05$ For differences between treatment with metoprolol and atenolol.

sity lipoprotein cholesterol increased by $8.9 \%(p=$ $0.0004)$ during treatment with metoprolol and $7 \cdot 1 \%$ $(p=0.003)$ during treatment with atenolol. Free fatty acid concentrations did not change significantly during any of the treatment periods.

\section{OTHER MEASUREMENTS IN BLOOD}

Packed cell volume increased by about $3 \%(p<0.05)$ during treatment with both metoprolol and atenolol. Serum urate and creatinine concentrations also increased by about $3 \%(p=0.09)$. All results of routine tests were within the normal ranges.

\section{ADVERSE REACTIONS}

Subjective symptoms were evaluated by visual analogue scales (table V). Difficulty in concentrating and vivid dreams were more pronounced during treatment with metoprolol than atenolol. There was also a tendency to more nightmares and insomnia when patients were taking metoprolol. Some patients reported other minor subjective side effects, but only one withdrew from the study (he developed cold hands and feet).

\section{Discussion}

Sensitivity to insulin decreased significantly during treatment with metoprolol $(20 \%)$ and atenolol $(13 \%)$.

TABLE IV-Adjusted mean serum cholesterol and triglyceride concentrations and plasma free fatty acid concentrations when patients took placebo, effects of metoprolol and atenolol, and difference between effects of the two drugs

\begin{tabular}{|c|c|c|c|c|c|}
\hline Variable & $\begin{array}{l}\text { During treatment } \\
\text { with placebo } \\
(n=60)\end{array}$ & $\begin{array}{c}\text { Effect of treatment } \\
\text { with metoprolol } \\
(n=58)\end{array}$ & $\begin{array}{c}\text { Effect of } \\
\text { treatment with } \\
\text { atenolol }(n=60)\end{array}$ & $\begin{array}{l}\text { Difference between } \\
\text { effects of metoprolol } \\
\text { and atenolol }\end{array}$ & $\begin{array}{c}\text { Square root } \\
\text { of residual } \\
\text { variance }\end{array}$ \\
\hline \multicolumn{6}{|l|}{ Serum cholesterol (mmol/): } \\
\hline Total & $6 \cdot 10$ & 0.00 & -0.08 & 0.08 & 0.39 \\
\hline VLDL & 0.62 & $+0 \cdot 20^{\star \star \star}$ & $+0 \cdot 14^{\star \star}$ & 0.05 & 0.23 \\
\hline LDL & 4.41 & -0.06 & $-0 \cdot 15^{\star \star}$ & 0.08 & 0.42 \\
\hline $\mathrm{HDL}$ & 1.03 & $-0.06^{\star \star}$ & $-0 \cdot 08^{\star \star \star}$ & 0.02 & $0 \cdot 10$ \\
\hline \multicolumn{6}{|l|}{ Serum triglycerides $(\mathrm{mmol} / \mathrm{l})$ : } \\
\hline Total & $2 \cdot 04$ & $+0.59 \star \star \star$ & $+0 \cdot 43^{\star \star \star}$ & $0 \cdot 15$ & 0.59 \\
\hline VLDL & $1 \cdot 26$ & $+0.54^{\star \star \star}$ & $+0.41^{\star \star \star}$ & $0 \cdot 13$ & 0.54 \\
\hline LDL & 0.55 & $+0.06^{\star \star \star}$ & $+0.04^{\star}$ & 0.02 & 0.09 \\
\hline HDL & $0 \cdot 21$ & +0.016 & 0.00 & 0.01 & 0.05 \\
\hline Plasma FFA & 0.59 & -0.02 & -0.04 & 0.02 & $0 \cdot 15$ \\
\hline VLDL triglycerides:VLDL cholesterol & $2 \cdot 20$ & $+0 \cdot 13^{\star}$ & $+0 \cdot 12^{\star \star}$ & 0.02 & 0.33 \\
\hline LDL triglycerides: LDL cholesterol & $0 \cdot 13$ & $+0.02^{\star \star \star}$ & $+0.02^{\star \star \star}$ & 0.00 & 0.02 \\
\hline LDL cholesterol:HDL cholesterol & 4.40 & $+0 \cdot 19^{\star}$ & +0.15 & 0.04 & 0.57 \\
\hline VLDL and LDL:HDL cholesterol & 5.07 & $+0.45^{\star \star \star}$ & $+0 \cdot 36^{\star \star}$ & 0.09 & 0.66 \\
\hline
\end{tabular}

$\mathrm{VLDL}=$ Very low density lipoprotein. $\mathrm{LDL}=$ Low density lipoprotein. $\mathrm{HDL}=$ High density lipoprotein. $\mathrm{FFA}=$ free fatty acids. ${ }^{\star} \mathrm{p}<0 \cdot 05,{ }^{\star \star} \mathrm{p}<0 \cdot 01$, $\star \star \star \mathrm{p}<0.001$ Compared with treatment with placebo. 
During a euglycaemic hyperinsulinaemic clamp study glucose uptake occurs when patients are hyperinsulinaemic and is directly related to insulin concentration. Despite higher steady state plasma insulin concentrations during treatment glucose uptake was decreased. Thus the decrease in glucose disposal mediated by insulin was, if anything, underestimated. The glucose uptake corrected for the steady state insulin concentration, which is probably a better estimate of the degree of change, was $27 \%$ and $23 \%$ lower during treatment with metoprolol and atenolol respectively (figure). The steady state insulin concentrations attained during the euglycaemic clamps reflect the rate of metabolic clearance of insulin. ${ }^{20}$ This may therefore be decreased by both metoprolol and atenolol. Two other studies have shown that clearance of insulin is reduced after blockade selective for the type of $\beta$ adrenergic receptor. ${ }^{21}{ }^{22}$

The reduction in sensitivity to insulin was also reflected by higher insulin and glucose concentrations during treatment with selective $\beta$ blockers compared with placebo, both when the patients were fasting and after they had received an intravenous glucose load. In subjects with normal insulin secretion decreased sensitivity to insulin is compensated for by an increase in the amount of insulin released in order to preserve glucose homoeostasis - for example, in obesity. In this study the decreased sensitivity to insulin and increased fasting insulin and glucose concentrations were accompanied by a small increase in insulin response during the glucose tolerance test. During treatment with metoprolol insulin concentrations increased by $13 \%$ during the last 30 minutes of the test compared with values during treatment with placebo. In two groups of 60 year old men with normal blood pressure and blood glucose concentrations a similar difference in glucose disposal mediated by insulin was associated with a $100 \%$ increase in insulin concentrations during the corresponding period of the glucose tolerance test (T Pollare, unpublished observations). Thus the possibility cannot be ruled out that $\beta$ selective adrenergic blockade, ${ }^{23}{ }^{24}$ like non-selective $\beta$ adrenergic blockade, suppresses insulin secretion and that this may be one cause of the deterioration in glucose tolerance found in our study. The increase in glycated haemoglobin concentrations, reflecting higher average blood glucose concentrations, is further evidence that low glucose disposal mediated by insulin leads to decreased glucose tolerance during $\beta$ selective blockade.

Treatment with non-selective $\beta$ adrenergic blockers such as propranolol has been reported to lead to worsened control in diabetic patients and is also occasionally associated with precipitation of diabetes. ${ }^{25}$ In some comparative studies, ${ }^{26-28}$ but not others, ${ }^{29}$ drugs selective for the $\beta_{1}$ receptor have offered some advantage over non-selective $\beta$ blockers. Most studies of carbohydrate metabolism during $\beta$ adrenergic blockade have been done on too few patients to show effects on fasting glucose and plasma insulin concentrations. This may explain why increased ${ }^{30} 31$ as well as decreased ${ }^{3132}$ and unchanged glucose tolerance and insulin responses ${ }^{33-35}$ have been found. With the intravenous insulin tolerance test as a crude measure one study found that both propranolol and metoprolol reduced sensitivity to insulin. ${ }^{36}$ Furthermore, DeFronzo et al showed that infusion of propranolol during a euglycaemic clamp significantly reduced glucose uptake mediated by insulin. ${ }^{37}$

The change in fasting blood glucose and plasma insulin concentrations observed in our study was small and unlikely to play an important part as a risk factor for cardiovascular morbidity and death. On the other hand, decreased sensitivity to the peripheral action of insulin may impair glucose tolerance and cause diabetes. A longitudinal study of 1462 women showed that treatment with $\beta$ blockers and thiazides was associated with a risk of diabetes in hypertensive patients. ${ }^{78}$ We report similar results for men in a separate paper in this issue ( $p$ 1147). The impaired glucose disposal mediated by insulin during euglycaemic clamp shown in this study during treatment with $\beta_{1}$ selective adrenergic blockers, and similar effects of saluretics ${ }^{39}$ may contribute to the precipitation of diabetes in susceptible people with hypertension. Both diabetes and impaired glucose tolerance increase the risk of cardiovascular disease. ${ }^{40}$

There are several possible explanations for the diminished glucose disposal mediated by insulin during $\beta_{1}$ selective adrenergic blockade. The decrease in cardiac output during $\beta$ blockade may lead to reduced blood flow in muscles, thereby reducing the availability of glucose to the prime target tissue for glucose disposal..$^{4142}$ There is further support for a haemodynamic explanation of the decreased sensitivity to insulin from studies of vasodilators, as prazosin' and captopril, ${ }^{43}$ both of which increase blood flow in skeletal muscle, increase sensitivity to insulin.

The density of capillaries in skeletal muscle correlates with plasma insulin concentration. ${ }^{44}$ Lillioja et al showed that insulin action is determined by the density of the capillary supply to skeletal muscle, particularly around the type 1 , oxidative, slow twitch fibres. ${ }^{45}$ Type 1 fibres are more sensitive to insulin and are equipped with more $\beta$ adrenergic receptors than type 2, glycolytic, fast twitch fibres. Subjects with a high proportion of slow twitch fibres are apparently more sensitive to the action of $\beta$ blockers as they have a more pronounced reduction in heart rate during treatment. ${ }^{46}$ The decrease in sensitivity to insulin during $\beta$ blockade in our study showed a weak $(r=0.33)$ but significant $(p=0.037)$ association with the change in heart rate. $\beta_{1}$ Selective blockers have been shown to reduce maximum oxygen uptake during an exercise test. ${ }^{46}$ Thus $\beta$ blockers may interfere with the capacity for glucose oxidation in insulin sensitive type 1 fibres. $\beta$ Blockade may also influence glucose metabolism by its effect on the release of growth hormone. ${ }^{14} 47$

Free fatty acid concentrations are either unchanged, as in our study, or decreased during $\beta$ blockade, thus excluding the possibility of resistance to insulin mediated by an increased supply of fatty acids to skeletal muscle. ${ }^{48}$ Our data support previous observations that free fatty acid concentrations return to pretreatment values after six months of treatment. ${ }^{49}$

An increase in body weight has been noted in other studies during $\beta$ blockade. ${ }^{5}$ The reason for this is not fully understood, although a lower metabolic rate may be contributory. ${ }^{3750}$ In our study weight gain was associated with a significant increase in waist circumference $(p=0.01)$ during treatment.

Our results confirm that $\beta$ selective blockade has little influence on serum cholesterol and low density lipoprotein cholesterol concentrations but decreases high density lipoprotein cholesterol concentration by about $7 \% .{ }^{51}$ The atherogenic index (very low density lipoprotein plus low density lipoprotein/high density lipoprotein cholesterol) increased significantly during both treatments. In agreement with other studies the most striking change in lipid metabolism during $\beta$ blockade was an increase in serum triglyceride and very low density lipoprotein triglyceride concentrations.

The changes in basal glucose and plasma insulin concentrations shown during $\beta$ selective blockade in this study may provide a link between insulin resistance and abnormal lipid metabolism. Increased serum triglyceride and decreased high density lipoprotein cholesterol concentrations are directly and inversely related to plasma insulin concentrations. There may, therefore, be a series of events which starts with a 
$\beta$ blocker inducing a decrease in glucose disposal mediated by insulin and eventually ends with an increased burden of risk factors for ischaemic heart disease. During this course of events an increased serum triglyceride concentration, decreased serum high density lipoprotein cholesterol concentration, and impaired glucose tolerance or diabetes are direct consequences of insulin resistance and hyperinsulinaemia. People who already have some resistance to insulin when essential hypertension is detected may be particularly susceptible to environmental influences that increase the resistance.

The metabolic side effects shown in this study are small, but as $30-50 \%$ of people over 60 are treated for hypertension in Sweden the effects of antihypertensive treatment on the incidence of ischaemic heart disease in the whole community should not be underestimated..$^{52}$ The association between antihypertensive treatment and resistance to insulin should be subject to further studies. Non-pharmacological treatments for hypertension should also be investigated, especially as such treatment may influence other risk factors for cardiovascular disease and death.

This study was supported by grants from the Swedish Medical Research Council, the Swedish Diabetes Association, the Ernfors Family Fund, the King Gustaf V Fund, the Heart and Lung Fund, and the Förenade Liv Mutual Life Insurance Corporation.

I Framingham Study Group. Systolic versus diastolic blood pressure and risk of coronary heart disease. Am $\mathcal{F}$ Cardiol 1971;27:335-46.

2 Veterans Administration Cooperative Study Group on Antihypertensive Agents. Effects of treatment on morbidity in hypertension. II. Results in patients with diastolic blood pressure averaging 90 through $114 \mathrm{~mm} \mathrm{Hg}$. FAMA 1970;213:1143-52.

3 Korner PL, Bauer GE, Doyle AE, et al. Untreated mild hypertension: a report by the management committee of the Australian therapeutic trial in mild by the management committee of

4 Helgeland A, Hiermann I, Leren P, Holme I. Possible metabolic side effects of beta-adrenergic blocking drugs. Br Med f 1978;i:828.

5 wilhelmsen $\mathrm{L}$, Berglund $\mathrm{G}$, Elmfeldt $\mathrm{D}$, et al. Beta-blockers versus diuretics in hypertensive men: main results from the HAPPHY trial. $\mathcal{f}$ Hypertens 1987;5:561-72

6 Medical Research Council Working Party. MRC trial of treatment of mild hypertension: principal results. Br Med f 1985;291:97-104.

7 Bengstsson C, Blohmé G, Lapidus L, et al. Do antihypertensive drugs precipitate diabetes? Br Med f 1984;289:1495-7.

8 Ferrannini E, Buzzigoli G, Bonadonna R, et al. Insulin resistance in essential hypertension. N Engl f Med 1987;317:350-7.

9 Pollare T, Lithell H, Selinus I, Berne C. Application of prazosin is associated with an increase of insulin sensitivity in obese patients with hypertension. Diabetologia 1988;31:415-20.

10 Manicardi V, Camelline L, Bellodi G, Coscelli C, Ferrannini E. Evidence for an association of high blood pressure and hyperinsulinemia in obese man. an association of high blood pressure and

11 Ikkos D, Luft R. On the intravenous glucose tolerance test. Acta Endocrinol (Copenh) 1957;25:312-34.

12 Jeppsson JO, Jerntorp P, Sundkvist G, Englund H, Nylund V. Measurement of hemoglobin $A_{1} C$ by a new liquid-chromatographic assay: methodology, clinical utility, and relation to glucose tolerance evaluated. Clin Chem

13 DeFronzo RA, Tobin JD, Andres R. Glucose clamp technique: a method for quantifying insulin secretion and resistance. Am $\mathcal{F}$ Physiol 1979;237:214-33.

14 Bratusch-Marrain PR, Smith D, DeFronzo RA. The effect of growth hormone on glucose metabolism and insulin secretion in man. $7 \mathrm{Clin}$ Endocrinol Metab 1982;55:973-82.

15 Rizza RA, Mandarino LJ, Gerich JE. Mechanism and significance of insulin resistance in non-insulin dependent diabetes mellitus. Diabetes 1981;30: 990-5.

16 Rizza RA, Mandarino LJ, Gerich JE. Dose-response characteristics for effects of insulin on production and utilization of glucose in man. Am $\mathcal{J}$ Physiol 1981;240:E630-9.

17 Bergman RN, Finegood DT, Ader M. Assessment of insulin sensitivity in vivo. Endocr Rev 1985;6:45-86.

18 DeFronzo RA, Ferrannini E, Hendler R, Felig P, Wahren J. Regulation of splanchnic and peripheral glucose uptake by insulin and hyperglycemia in man. Diabetes 1983:32:35-45.

19 SAS Institute. SAS user's guide: statistics. Cary, North Carolina: SAS Institute, 1982.

20 Davidson $M B$, Harris MD, Rosenberg CS. Inverse relationship of metabolic clearance rate of insulin to body mass index. Metabolism 1987;36:219-22.

21 Clausen Siöbom N, Lins PE, Adamson U, Curstedt T, Hamberger B. Effects of metoprolol on the counterregulation and recognition of prolonged hypoglycaemia in insulin-dependent diabetics. Acta Med Scand 1987;222: 57-63.

22 Schlüter KJ, Kerp L. Beta-adrenoceptor blocking agents induce different counterregulatory responses to insulin. Fournal of Pharmacology (Paris) $1983 ; 14$ (suppl 2):49-60
23 Loubatières A, Mariani MM, Sorel G, Savi L. The action of beta-adrenergic locking and stimulating agents on insulin secretion. Characterization of the type of beta receptor. Diabetologia 1971;7:127-32.

24 William-Olsson T, Fellenius E, Björntorp P, Smith U. Differences in metabolic responses to beta-adrenergic stimulation after propranolol or metoprolol administration. Acta Med Scand 1979;205:201-6.

25 Podolsky S, Pattavina CG. Hyperosmolar nonketotic diabetic coma: a complication to propranolol therapy. Metabolism 1973;22:685-92.

26 Waal-Manning HJ. Metabolic effects of beta-adrenoceptor blockers in hypertension. Drugs 1976;11(suppl 1):121-6.

27 Micossi P, Pollavini G, Raggi U, Librenti MC, Garimberti B, Beggi P. The effects of metoprolol and propranolol on glucose tolerance and insulin secretion in diabetes mellitus. Hormone Metab Res 1984;16:59-63.

28 Holm G, Johansson S, Vedin A, Wilhelmsson C, Smith U. The effect of betablockade on glucose tolerance and insulin release in adult diabetes. Acta Med Scand 1980;208:187-91.

29 Wright AD, Barber SG, Kendall MJ, Poole PH. Beta-adrenoceptor-blocking drugs and blood sugar control in diabetes mellitus. $\mathrm{Br} M e d ~ F$ 1979;i:159-61.

30 Helgeland A, Hagelund CH, Strömmen R, Tretli S. Enalapril, atenolol, and hydrochlorothiazide in mild to moderate hypertension. Lancet 1986;i:872-5.

1 Birnbaum J, DiBianco A, Becker KL, et al. Glucose and lipid metabolism during acebutolol and propranolol therapy of angina in non-diabetic patients. Clin Pharmacol Ther 1983;33:294-300.

32 Lehtonen A. The effect of acebutolol on plasma lipids, blood glucose and serum insulin levels. Acta Med Scand 1984;216:57-60.

33 Vedin A, Wilhemsson C, Bï̈rntorp P. Induction of diabetes and oral glucose tolerance tests during and after chronic beta-blockade. Acta Med Scand 1975;199 (suppl 575):37-40.

34 Hedstrand $\mathrm{H}$, Aberg $\mathrm{H}$. Insulin response to intra-venous glucose during longerm treatment with propranolol. Acta Med Scand 1974;196:39-40.

35 Ekberg G, Hansson BG. Glucose tolerance and insulin release in hypertensive patients treated with the cardioselective beta-receptor blocking agent metoprolol. Acta Med Scand 1977;202:393-7.

36 Tötterman K, Groop L, Groop PH, Kala R, Tolppanen EM, Fyhrqvist F. Effects of beta-blocking drugs on beta-cell function and insulin sensitivity in hypertensive non-diabetic patients. Eur f Clin Pharmacol 1984;26:13-7.

37 DeFronzo RA, Thorin D, Felber JP, et al. Effect of beta and alpha adrenergic blockade on glucose-induced thermogenesis in man. $\mathcal{F}$ Clin Invest 1984;73: 633-9.

38 Bengtsson C, Blohmé G, Lapidus L, Lundgren H. Diabetes in hypertensive women: an effect of antihypertensive drugs or the hypertensive state per se? Diabetic Med 1988;5:261-4.

39 Helderman JH, Elahi D, Andersen DK, et al. Prevention of the glucose intolerance of thianic

$40 \mathrm{Jarrett} \mathrm{JR}$. The epidemiology of coronary heart disease and related factors in the context of diabetes mellitus and impaired glucose tolerance. In: Jarrett the context of diabetes mellitus and impaired glucose tolerance. In:
RJ, ed. Diabetes and heart disease. Amsterdam: Elsevier, 1984:1-23.

41 Trap-Jensen J, Clausen JP, Noer I, Larsen OA, Krogsgaard AR, Christensen $\mathrm{NJ}$. The effects of beta-adrenoceptor blockers on cardiac output, liver blood flow and skeletal muscle blood flow in hypertensive patients. Acta Physiol Scand 1976;suppl 440:14-28.

42 Smith RS, Warren DJ. Effect of acute oral beta adrenergic blockade on muscle blood flow in man. Cardiovasc Res 1982;16:205-8.

43 Jauch KW, Hartl W, Guenther B, Wicklmayr M, Rett K, Dietze G. Captopril enhances insulin responsiveness of forearm muscle tissue in non-insulindependent diabetes mellitus. Eur $\mathcal{F}$ Clin Invest 1987;17:448-54.

44 Lithell $\mathrm{H}$, Lindgärde F, Hellsing K, et al. Body weight, skeletal muscle morphology and enzyme activities in relation to fasting serum insulin concentration and glucose tolerance in 48-year-old men. Diabetes 1981;30: 19-25.

45 Lillioja S, Young AA, Culter CL, et al. Skeletal muscle capillary density and fibre type are possible determinants of in vivo insulin resistance in man. fibre type are possible determinant

46 Kaiser $P$. Physical performance and muscle metabolism during beta-adrenergic blockade in man (thesis). Acta Physiol Scand 1984;suppl 536:1-53.

47 Mauras N, Blizzard RM, Thorner MO, Rogol AD. Selective beta ${ }_{1}$-adrenergic receptor blockade with atenolol enhances growth hormone releasing hormone and mediated growth hormone release in man. Metabolism 1987;36:369-72.

48 Ferrannini E, Barrett EJ, Bevilacqua S, De Fronzo RA. Effect of fatty acids on glucose production and utilization in man. $\mathcal{F}$ Clin Invest 1983;72:1737-47.

9 Day JL, Simpson N, Metcalfe J, Page RL. Metabolic consequences of atenolol and propranolol in treatment of essential hypertension. $B r \operatorname{Med} \mathcal{F}$ 1979; ; $77-80$

50 Faber $\mathrm{B}$, Liedholm $\mathrm{H}$, Monti $\mathrm{M}$. Thermogenesis in human skeletal muscle as measured by direct microcalorimetry and muscle contractile performance during beta-adrenoceptor blockade. Clin Sci 1986;70:435-41.

51 Singer P, Gödicke W, Voigt S, Hajdu I, Weiss M. Post-prandial hyperinsulinemia in patients with mild essential hypertension. Hypertension 1985;7:182-6.

52 Drug Information Committee of the Swedish National Board of Health and Welfare. Workshop on the treatment of mild hypertension 1987;1:81-6.

(Accepted 14 February 1989)

\section{Correction}

Prevalence of diabetes in a predominantly Asian community: preliminary findings of the Coventry diabetes study

A printers' error occurred in the list of authors of this paper by Dr D Simmons and others (7 January, p 18). The first author is Dr D Simmons and not Dr S Simmons as published on the cover of this issue. 